\title{
Relation Between Locus of Control of College Teachers and Their Job Satisfaction
}

\author{
Neha Mahajan ${ }^{1, *}$, Jas deep Kaur ${ }^{2}$ \\ ${ }^{1}$ Department of Education, Sewa Devi S.D.College of Education, Tarn Taran, Punjab, India \\ ${ }^{2}$ D.A.V.College of Education for women, Amritsar, Punjab, India
}

\begin{abstract}
The purpose of study was to understand the relationship between locus of control of college teachers and their job satisfaction. A sample of 150 teachers was selected fro $m$ the different colleges of A mritsar city in Punjab, India. The tools used were locus of control scale and job satisfaction scale. The different statistical techniques like Pearson's product moment coefficient of correlation, Mean, Standard error of difference between means and T- test were used for the study. The study reveals a significant relationship between locus of control and job satisfaction of college teachers. Among male and female teachers, male teachers with high job satisfaction possess a better locus of control as compared to female college teachers with high job satisfaction.
\end{abstract}

Keywords Locus of Control, Job Satisfaction, College Teachers

\section{Introduction}

Empo werment, learning and problem solving are importa nt assets for any human being wishing to reach his full potential and to deal with different problems. But in modern day society, the needs and desires of human are ever widening and ever en larging leading to so many problems. So, when his desires remain unfulfilled, he becomes depressed and unhappy. In such situations, different people perceive differently, the various situations arising due to unfulfillment of their desires, thereby affecting their behaviour. Some people hold chance, fate, God and other people responsible for the happenings of their life events while there are some people who believe in themselves, their own efforts and do hard work that leads to contentment and eternal happiness. Psychologically, this aspect of behaviour is called "Locus of Control".

\subsection{Locus of Control}

The concept of Locus of control was first proposed by Rotter[1] means power of directing. Ety mologically, locus of control tells about the place where our behaviour gets directions. It must be remembered that locus of control is a concept that has a significant effect on our daily lives.

Rotter believed that if one finds a link between behaviour and reinforces, then one's behaviour is affected by the reinforce. Worchel and Goethals [2] conclude that difference

* Corresponding author:

nhgp84@gmail.com (Neha Mahajan)

Published online at http://journal.sapub.org/ijap

Copyright (C) 2012 Scientific \& Academic Publishing. All Rights Reserved in perceived locus of control is important for adjustment in the world. Copper[3] stated locus of control as an important factor for achievement in life. Those with external locus of control believed that environmental causes and situational factors as being more important than their own or internal factors $[4,5]$. But those with internal locus of control see the world through a more adaptive perspective. They believe that hard work and personal abilities will lead to positive outcomes. This makes them more likely to meet challenges and succeed in their endeavours.

\subsection{Job S atisfaction}

Another variable that is important to this study is job satisfaction. In general satisfaction is defined as fulfillment or gratification of desires, feelings, contentment, happiness and optimis $m$. So, Job satisfaction refers to inner contentme nt or happiness for an employee engaged in any job. It can be described as a positive emotional state resulting from evaluating one's job experiences and job dissatisfaction occurs when these expectations are not met[6]. It is a source of satisfaction of physiological, psychological and sociologi cal needs of an individual in his work. Job satisfaction is overall a feeling about one's job or carrier (compensation, autonomy, co-workers) which can be related to specific outcomes such as productivity. Robbins [7] described job satisfaction as an individual's general attitude towards the job. A person with a high level of job satisfaction holds positive attitude towards the job. Locke[8] defined job satisfaction as employee's affective response to various aspects of the job or job situations. According to Cranny et al[9], job satisfaction is an effective reaction that results from the incumbents' comparison of actual outcomes with 
those that are desired. Stansbury and Zimmerman[10] concluded from their studies that job satisfaction is related to working conditions and level of professionalis $m$ is the key to success. Different researchers co-relates teacher autonomy to their job satisfaction $[11,12]$.

\subsection{Relation between Loc us of Control and Job Satisfaction}

Locus of control is a very important parameter for understanding the job satisfaction of a teacher. It may be understood as bipolar construct hanging from external to internal locus of control. Those who make choices primarily on their own and believe that control of future outcomes resides primarily in oneself are said to have internal loci or internal control while those who make decisions based more on what others desire and believe in the expectancy that control of events is outside oneself, either in the hands of other powerful persons or due to fate and chance, the decisions of their life are said to have external loci or external control. Generally stated, persons with a strong belief in internal control are more confident and assertive and are active searchers for information that help them to achieve their own objectives and are attracted to situations that offer opportunities of achievement. Spector[4,5] found that individuals with an internal locus of control should be more job satisfied because they were less likely to stay in a dissatisfying jobs and were more likely to be successful in organizations. Similarly, Kinick and Vecchio[13] reported that individuals who have internal loci are likely to be more committed to their organization than those who have external loci. Plumly and Oliver[14] discuss the significant influence of locus of control on the job search process. Individuals with an internal locus of control are found to engage in mo re systematic exploration and have more information than externals [15]. This suggests that an external orientation may reduce motivation to demonstrate certain types of explorato ry behaviour. Cumins[16] conducted a study to examine the relationship between social support and locus of control in determining job satisfaction levels and stress. He found that the individuals with an internal loci were shown to be more satisfied with their jobs regardless of the stress levels while those with an external loci tended to be less satisfied with their job and relied upon supervisory support to reduce stress. Kasperson[17] completed a study of hospital employees, which revealed a high positive corre lation between negative attitude and external locus of control which resulted in a low satisfaction level with the job while those with positive attitude were generally more satisfied with outcomes because of the amount of control they had to make thing happen. Bruno[18] studied the influence of locus of control and job satisfaction on organizational commitment and found that the combination of work locus of control and job satisfaction could significantly influence the organizational commitment of medical records personnel in university teaching hospitals. Coleman et a1.[19] conducted a study on the relationship between work locus of control and organiza tional commitment. The results revealed that internal work locus of control were re lated to affective commitment, while external work locus of control was associated with continua nce commitment. Relationship between job characteristics, internal locus of control and job satisfaction of teachers was also studied by others[20-24]. Judge et al.[25] explored the effect of core evaluations on job satisfaction and life satisfaction. They found a significant relationship between self-esteem, generalized self-efficiency, locus of control, neuroticism and work outcomes. Even though one's actions may not have anything to do with an outcome, the belief that one can do greatly aid one's psychological well-being. The psychological well-being of a teacher is all the more important as he is the corner stone of entire educational arch. If teacher is satis fied with h is job, only then he will be happy, stable and leads a contented life but if he is unwell, all the time remains depressed and disturbed then he will do more harm than any good. So, locus of control seems to play an important role in the job satisfaction of a teacher. It is said "No one can rise above the level of a teacher." These words stress the need to pay attention towards the fact that if we want to have a good educational programme, we must have competent and contented teachers.

\section{Objectives of the study}

Following were the objectives of the present study:-

$>$ To study relationship between locus of control of college teachers and their job satis faction.

$>$ To study the locus of control of male and female college teachers in relation to their job satisfaction.

The following hypothesis were drawn for the study

* There exists a significant relationship between locus of control of college teachers and their job satisfaction.

* Male college teachers with high job satis faction will not differ significantly in respect of locus of control from male college teachers with low job satisfaction

* Male college teachers with high job satis faction will not differ significantly in respect of locus of control from female college teachers with high job satis faction

* Female college teachers with high job satisfaction will not differ significantly in respect of locus of control from female college teachers with low job satisfaction in respect of locus of control.

* Female college teachers with low job satisfaction will not differ significantly in respect of locus of control from male college teachers with low job satisfaction in respect of locus of control.

\section{Method}

The present study was designed to study the relationship between locus of control and job satisfaction of college teachers. In order to study this, descriptive survey method of investigation was employed. It is an organized attempt to 
analyse, interpret and report the present status of a social institution, group or area.

\subsection{Sample}

For the collection of relevant data, the sample in the present study includes 150 college teachers from various colleges of Amritsar city (Punjab) only. The samples consist of both male and female college teachers.

\subsection{Tools used for the Study}

Locus of control scale (Internal-External Scale) - By Roma Pal[26]

$>$ Job satisfaction Scale - By S.K. Saxena[27]

The purpose ofboth the scales was clearly exp lained to the subjects. It was assured that their replies would be kept confidential. The subjects were requested to read instructions carefully and to ask the tester, if there was any difficulty in understanding the instruction. It was emphasized that no item should be omitted and there was nothing "right" and "wrong" about these questions. There was no time limit for the questionnaire. However, it took approximately 30 minutes to complete it.

\section{Results and Discussion}

To verify the above framed hypotheses, first of all data was collected from different college teachers of Amritsar city (Punjab) using locus of control scale and job satisfaction scale. The raw scores thus obtained were then tabulated for studying the locus of control as well as job satisfaction level of teachers from different colleges according to the criteria given in the manual of locus of control scale and job satisfaction scale respectively. Further, to verify the above stated hypotheses firstly Pearson's Product Moment Coefficient of Correlation (r) was calculated between locus of control and job satisfaction for the total sample as well as for male and female college teachers separately.

Then, in order to find the high and low level of job satisfaction among male and female college teachers, Kelley's formula was used (according to which the upper $27 \%$ and lower $27 \%$ of the sample served as criterion groups). Using this formula, the number of college teachers falling in high and low level of job satisfaction were calculated and given in table 1

Table 1. Number of college teachers falling in different categories of job satisfaction

\begin{tabular}{ccccc}
\hline Category & $\begin{array}{c}\text { High job } \\
\text { satisfaction }\end{array}$ & $\begin{array}{c}\text { Low job } \\
\text { satisfaction }\end{array}$ & $\begin{array}{c}\text { Average job } \\
\text { satisfaction }\end{array}$ & Total \\
\hline Male & 20 & 20 & 35 & 75 \\
\hline Female & 20 & 20 & 35 & 75 \\
\hline Total & 40 & 40 & 70 & 150 \\
\hline
\end{tabular}

Thus, from the above table, it was found that a total of 70 college teachers ( 35 male and 35 female) fall in the category of average job satisfaction whereas 40 male and 40 female college teachers belong to high and low groups respectively. However, it was observed that teachers having average level of job satisfaction, possessed average locus of control and according to manual of locus of control, persons having average locus of control, are regarded to have balanced personality.

\subsection{Hypothesis 1: there Exists a Significant Relations hip between Locus of Control of College Teachers and their Job Satisfaction}

For the verification of above hypothesis, Pearson's product mo ment coefficient of correlation (r) was calculated between locus of control and job satisfaction for the total sample as well as for male and female college teachers separately. In order to calculate $r$, mean scores were calculated for the total sample of 150 and for 75 males and 75 females separately on the variable of job satisfaction and locus of control respectively. The calculated value of ' $r$ ' has been shown in the table 2 .

Table 2. R-value on the variable of locus of control and job satisfaction

\begin{tabular}{cccc}
\hline Sample & $\mathrm{N}$ & $\mathrm{R}$ & Level of significance \\
\hline Male college teachers & 75 & 0.64 & Significant at .01 \\
\hline $\begin{array}{c}\text { Female college } \\
\text { teachers }\end{array}$ & 75 & 0.61 & Significant at .01 \\
\hline Total sample & 150 & 0.6 & Significant at .01 \\
\hline
\end{tabular}

Table 2 shows correlation coefficient i.e. r-value of 0.64 and 0.61 for the male and female college teachers respectively on the variable of locus of control and job satisfaction, which come out to be significant at 0.01 level. This result clearly indicates that there exists a significant relationship between locus of control and job satisfaction of male and female college teachers. It also depicts correlation coefficient i.e. r-value of 0.6 for the total sample of 150 college teachers which is also significant. Therefore, it can be inferred from this value, that locus of control and job satisfaction of college teachers are related to each other.

Thus, the above hypothesis is in line of confirmation with the assumption of the investigator that the said variables i.e. locus of control and job satisfaction are related to each other. Hence, this hypothesis is accepted in the light of above discussion.

\subsection{Hypothesis 2: Male College Teachers with High Job Satisfaction will Differ Significantly in Respect of Locus of Control from Male College Teachers with Low Job Satisfaction}

For the verification of above hypothesis, mean and standard deviation scores on the variable of locus of control were calculated for the two group of males, having high and low job satisfaction respectively. In order to see the significance of difference between the means of two 
samples, 't'-test of significance was applied. The calculated tvalue has been shown in the table 3 .

Table 3. Mean, standard deviation and t-ratio on the variable of locus of control of male college teachers with high and low job sat isfaction

\begin{tabular}{ccccc}
\hline & Samples & $\begin{array}{c}\text { Mean } \\
\mathrm{M}\end{array}$ & $\begin{array}{c}\text { Standard } \\
\text { Deviation } \\
\sigma\end{array}$ & T-Ratio \\
\hline $\begin{array}{c}\text { Male college } \\
\text { teachers with } \\
\text { high job } \\
\text { satisfaction }\end{array}$ & 20 & 57.8 & & \\
\hline $\begin{array}{c}\text { Male college } \\
\text { teachers with } \\
\text { low job } \\
\text { satisfaction }\end{array}$ & 20 & 51.8 & 2.45 & $7.8^{* *}$ \\
\hline
\end{tabular}

*stands for significance at 0.05 level,

** stands for significance at 0.01 level

Table 3 shows that mean values of locus of control of male college teachers with high and low job satisfaction are 57.8 and 51.8 respectively. The calculated t-value of 7.8 , a mong male college teachers with high and low job satisfaction on the variable locus of control was found significant at 0.01 level leading to the acceptance of hypothesis no. 2. This indicates that male college teachers with high job satisfaction differed significantly in respect of locus of control from male college teachers with low job satisfaction. Also, higher mean score in favour of male college teachers with high job satisfaction signified that this group possesses better locus of control in the present sample as compared to male college teachers with low job satisfaction.

\subsection{Hypothesis 3: Male College Teachers with High Job Satisfaction will not Differ Significantly in Respect of Locus of Control From Female College Teachers with Low Job Satisfaction}

For the verification of third hypothesis, Mean and Standard Deviation scores were calculated for males having high job satisfaction and females having low job satisfaction on the variable of locus of control. In order to see the significance of difference between the means of two samples, ' $t$ '-test of significance was applied. Then t- value has been calculated. All these values have been presented in the table 4.

Table 4. Mean, standard deviation and t-ratio on the variable of locus of control of male college teachers with high job satisfaction and female collegeteachers with low job satisfaction

\begin{tabular}{|c|c|c|c|c|}
\hline & $\begin{array}{l}\text { Sample } \\
\text { N }\end{array}$ & $\begin{array}{c}\text { Mean } \\
\text { M }\end{array}$ & $\begin{array}{c}\text { Standard } \\
\text { Deviation } \\
\sigma\end{array}$ & T-Rat io \\
\hline $\begin{array}{l}\text { Male college } \\
\text { teachers with high } \\
\text { job satisfaction }\end{array}$ & 20 & 57.8 & & \\
\hline $\begin{array}{l}\text { Female college } \\
\text { teachers with low } \\
\text { job satisfaction }\end{array}$ & 20 & 55.35 & 2.93 & $52.7 * *$ \\
\hline
\end{tabular}

Table 4 shows that mean values of locus of control of male college teachers with high job satisfaction and female college teachers with low job satisfaction are 57.8 and 55.35 respectively. Also, the calculated t-value of 52.7 as embodied in above table came out to be highly significant. It can, therefore, be inferred that above hypothesis is not confirmed implying that there exist a significant difference among male college teachers with high job satisfaction from their female counterparts with low job satisfaction in respect of locus of control. So, in the present sample, higher mean score in favour of male college teachers with high job satisfaction reveal that this group possess a better locus of control as compared to female college teachers with low job satisfaction.

\subsection{Hypothesis 4: Female College Teachers with High Job Satisfaction will Differ Significantly in Res pect if Locus if Control from Female College Teachers with Low Job Satisfaction}

For the verification of fourth hypothesis, mean and standard deviation scores were calculated for females having high job satisfaction and females having low job satisfaction on the variable of locus of control. In order to see the significance of difference between the means of two samples, ' $t$ '-test of significance was applied. Then calculated t- value has been calculated. All these values have been reported in the table 5

Table 5. Mean, standard deviation and t-ratio on the variable of locus of control of female college teachers with high and low job satisfaction

\begin{tabular}{ccccc}
\hline & $\begin{array}{c}\text { Sample } \\
\mathrm{N}\end{array}$ & $\begin{array}{c}\text { Mean } \\
\mathrm{M}\end{array}$ & $\begin{array}{c}\text { Standard } \\
\text { Deviation } \\
\sigma\end{array}$ & T-Ratio \\
\hline $\begin{array}{c}\text { Female college } \\
\text { teachers with } \\
\text { high job } \\
\text { satisfaction }\end{array}$ & 20 & 55.35 & & \\
\hline $\begin{array}{c}\text { Female college } \\
\text { teachers with } \\
\text { low job } \\
\text { satisfaction }\end{array}$ & 20 & 51.1 & 2.5 & $5.4^{* *}$ \\
\hline
\end{tabular}

*stands for significance at .05 level

**stands for significance at .01 level

Table 5 depicts the t- ratio of 5.4 among females with high and low job satisfaction on the variable of locus of control, which is again significant. Also, the mean values of locus of control of females with high and low job satisfaction on the variable of locus of control are found to be 55.35 and 51.1 respectively. Thus, the fourth hypothesis is accepted, indicating that there exists a significant difference among females with high and low job satis faction in respect of locus of control. This implies that their level of job satisfaction is affected if there is an increase or decrease in the level of locus of control. As mean score of female college teachers with high job satisfaction is more than female college teachers with low job satisfaction, so the above difference pointed out that female college teachers with high job satisfaction possess a better locus of control. 


\subsection{Hypothesis 5: Female College Teachers with Low Job Satisfaction will not Differ Significantly in Respect of Locus of Control From Male College Teachers with Low Job Satisfaction}

Table 6. Mean, standard deviation and t-ratio on the variable of locus of control of female and male college teachers with low job satisfaction

\begin{tabular}{|c|c|c|c|c|}
\hline Samples & $\begin{array}{c}\text { Sample } \\
\mathrm{N}\end{array}$ & $\begin{array}{c}\text { Mean } \\
\mathrm{M}\end{array}$ & $\begin{array}{c}\text { Standard } \\
\text { Deviation } \\
\sigma\end{array}$ & T-Ratio \\
\hline $\begin{array}{c}\text { Female college } \\
\text { teachers with } \\
\text { low job } \\
\text { satisfaction }\end{array}$ & 20 & 51.8 & & \\
\hline $\begin{array}{l}\text { Male college } \\
\text { teachers with } \\
\text { low job } \\
\text { satisfact ion }\end{array}$ & 20 & 51.1 & 1.91 & 1.17 \\
\hline
\end{tabular}

For the verification of fifth hypothesis, mean and standard deviation scores were calculated for females and males having low job satisfaction on the variable of locus of control. In order to see the significance of difference between the means of two samples, ' $t$ '-test of significance was applied. Then, $t-$ value has been calculated. All these values have been reported in the table 6 .

Table 6 depicts the t- ratio of 1.17 among females and males with low job satisfaction on the variable of locus of control, which is insignificant. The mean value in both groups is almost similar. However, the insignificant t-value justify the assumption of the investigator that there exists no significant difference in the locus of control of female and male college teachers having low job satisfaction. So, in case of group with low job satisfaction, locus of control is independent of sex differences.

\section{Conclusions}

In the light of the analysis and interpretation of the data mentioned in the previous chapter, following conclusions were drawn:

1. There exists a significant relationship between locus of control and job satisfaction of male and female college teachers i.e. it was inferred that locus of control and job satisfaction of college teachers were related to each other.

2. Male college teachers with high job satisfaction differ significantly in respect of locus of control from male college teachers with low job satisfaction and higher mean score in favour of male college teachers with high job satisfaction signifies that this group possess a better locus of control in the present sample as compared to male college teachers with low job satisfaction.

3. There exists a significant difference among male college teachers with high job satisfaction from their female counterparts with low job satisfaction in respect of locus of control. Higher mean score in favour of male college teachers with high job satisfaction reveals that this group possess a better locus of control as compared to female college teachers with low job satisfaction.

4. There exists a significant difference among females with high and low job satisfaction in respect of locus of control. This implies that their level of job satisfaction is affected if there is an increase or decrease in the level of locus of control. As mean score of female college teachers with high job satisfaction is more than female college teachers with low job satisfaction, the female college teachers with high job satisfaction possess a better locus of control.

5. A mong low group of job satisfaction, it is found that locus of control is independent of sexd ifferences.

\section{Recommendations}

The investigator would like to advance some suggestions for the prospective research workers who may be interested in undertaking similar type of study.

1. First of all, the study depicting the locus of control of college teachers in relation to their job satisfaction may be conducted on a large sample to obtain more accurate and reliable results.

2. The study of locus of control of college teachers in relation to their job satisfaction may also be carried out at different levels viz. primary, secondary and University stage.

3. Teachers working in the rural areas may also be included in the study.

4. The study of locus of control of college teachers can also be taken with variables other than job satisfaction such as socio -economic status, social maturity and health etc.

5. Undoubtedly, Pearson's coefficient measures both the degree and direction of the correlation between two variables but it has some limitations viz. It assumes a linear relationship between the variables even though it may not be there, It is tedious to calculate, It is unduly affected by the values of extreme items. So, it is recommended to take $2 * 2$ ANOVA design into consideration for the future studies.

\section{REFERENCES}

[1] Rotter J.B., General expentancies for external versus internal control of reinforcement, Psychological Monograph, 80 (1966) 609-615.

[2] Worchel S., Goethals R., Adjustment pathways to personal growth, N.J. Prentice Hall Inc. Eagle Wood Cliffs, 1985.

[3] Copper R., Individuality and connectedness in the family as context for adolescent identity formation and role-taking skills, New directions for Child and Adolescent Development, 22 (1983) 43-59.

[4] Spector, P.E. (1982). Behaviour in organizations as a function of employee's locus of control. Psychological Bulletin, 91 (1982) 482-497 
[5] Spector, P.E. (1988). Development of the work locus of control scale. Journal of Occupational Psychology, 61 (1988) 335-340.

[6] Mathis, R.L., Jackson, J.H., Human resource management. 9th ed. Cincinnati, Ohio: South Western College Publishing, 2000.

[7] Robbins, S.P., Organizational behaviour. 8th ed. New Jersey: Prentice Hall Inc., 1998

[8] Locke, E.A., The nature and cause of job satisfaction. InM.D. Dunnette (Ed.) Handbook of Industrial and organizational psy chology. Chicago: Rand MC Nally, 1976

[9] Cranny C.J., Smith P.C., Stone E.F., Job satisfaction: How people feel about their jobs and how it affects their performance, Lexington Books, New York,1992.

[10] Stansbury K., Zimmerman J., Lifelines to the classrooms: Designing support for beginning teachers, Knowledge Brief., San Francisco, CA,2000.

[11] Hoyle E., John P., Professional Knowledge and Professional Practice, London and New York: Cassell, 1995.

[12] Robertson S.L., Teacher's work, restructuring, and postfordism: Constructing the new professionalism, Falmer press, London, 1996.

[13] Kinicki, A.J., Vecchio, R.P., Influences on the quality of supervisorsubordinate relations: The role of time-pressure organizational commitment and locus of control. Journal of Organizational Behaviour, 15 (1994) 75-82.

[14] Plumly, W. L., Oliver, J. E. (1987), The locus of control attribute and the job search process, Psychological Reports, 61 (1987) 907-910.

[15] Noe R. A., Steffy, B. D., The influence of individual characteristics and assessment center evaluation on career exploration behavior and job involvement, Journal of Vocational Behavior, 30 (1987) 187-202.

[16] Cumins (1989). Locus of control and social support: clarifiers of the relationship between job stress and job satisfaction, Journal of Applied Social Psychology, 19 (1989) 772-788.
[17] Kasperson, C.J., Locus of control and job dissatisfaction, Psychological Reports, 50 (1982) 823-826.

[18] Bruno I., Influence of Locus of control and job satisfaction on Organizational Commitment: A Study of Medical records personnel in University teaching hospitals in Nigeria, Library Philosophy and Practice (2011), http://unllib.unl.edu/LPP/

[19] Coleman, D. F., Irving, G.P., Cooper, C.L., Another look at the locus of control, organizational commitment relationship; it depends on the form of commitment. Journal of Organizational Behaviour, 20 (1999) 995-1001.

[20] Boone, C.W., The relationship between job characteristics, role conflict, role ambiguity, internal locus of control and job satisfaction of college and university administrators, Dissertation, Abstracts International, 47 (1987) 3676 .

[21] Eichinger J., International Journal of disability. Development and education: Job stress and satisfaction among special education teachers: Effects of gender and social role orientation, 47 (2000) 397-412.

[22] Hoppock, R., Work adjustment and job satisfaction of teachers. Delhi: Mittal publications, 1935

[23] Hough.J., A meta-analytic study on relationship between locus of control and job performance, Journal of applied psychology, 57 (1992) 94-108.

[24] Kochar, G.K., Khetarpal, A., A study of stress, job satisfaction and locus of control in permanent and temporary college teachers, Journal of All India Educational Research,18 (2006) 106-109.

[25] Judge T.A., Bono J.E., Locke, E.A., Personality and job satisfaction: The mediating role of job characteristics , Journal of applied psy chology 85 (2000) 751-765.

[26] Roma P., Manual for locus of control scale ( InternalExternal Scale) for adolescents and adults: Agra: Psychological Research cell.

[27] Saxena, S.K., Manual for job satisfaction scale for teachers. Agra: Psychological Research cell. 